\title{
Mineralogical Characterization of Heavy Mineral Concentrates from Senegalese Great Cost by Using Qemscan and SEM
}

\author{
Moumar Dieye1, Marieke Van Lichtervelde², Abdoul Aziz Ndiaye1, Mamadou Gueye, \\ Simon B. Blancher ${ }^{3}$
}

${ }^{1}$ Earth Science Institute, Cheikh Anta Diop Dakar University, Dakar, Senegal

${ }^{2}$ Geosciences Environnement Toulouse, UPS, CNRS, IRD, Toulouse, France

${ }^{3}$ Eramet Ideas, Trappes, France

Email: moumar.dieye@ucad.edu.sn,dieyemoumar@gmail.com

How to cite this paper: Dieye, M., Van Lichtervelde, M., Ndiaye, A.A., Gueye, M. and Blancher, S.B. (2020) Mineralogical Characterization of Heavy Mineral Concentrates from Senegalese Great Cost by Using Qemscan and SEM. International Journal of Geosciences, 11, 800-817. https://doi.org/10.4236/ijg.2020.1112041

Received: November 24, 2020

Accepted: December 21, 2020

Published: December 24, 2020

Copyright $\odot 2020$ by author(s) and Scientific Research Publishing Inc. This work is licensed under the Creative Commons Attribution International License (CC BY 4.0).

http://creativecommons.org/licenses/by/4.0/

\begin{abstract}
The heavy mineral sands of Senegal are exploited to extract titanium oxides and zircon. Mining is carried out first by means of a floating dredge and concentration plant which produces a heavy mineral concentrate (HMC) containing on average $78 \%$ titanium oxides, $11 \%$ zircon and a set of silicate and alumino-silicate minerals. This heavy mineral concentrate is then treated by gravity, magnetic and electrostatic separation to produce titanium oxide concentrates (ilmenite, leucoxene, rutile) and three varieties of zircon concentrates (Premium zircon, standard zircon and medium grade zircon standard). In this study, we describe the various mineral concentrates in terms of mineralogical assemblages, and textural variability within grains, using Qemscan and Scanning Electron Microscopy. The titanium oxide concentrates are differentiated by their $\mathrm{TiO}_{2}$ content and vary from ilmenite to rutile. The zircon concentrates are characterized by the presence of impurities in the zircons, which consist in numerous inclusions of titanium oxides and silicate minerals. The mineralogical characteristics determined by scanning electron microscopy and by Qemscan showed great variability within the grains themselves. Heavy minerals contain many mineral inclusions and show strong chemical zoning.
\end{abstract}

\section{Keywords}

Heavy Mineral Sand, Qemscan, SEM, Origin

\section{Introduction}

Heavy mineral sands (HMS) present a great economic interest. They are ex- 
ploited to extract mainly minerals such as titanium oxides (ilmenite, rutile), and zircon. In the vast majority of HMS, ilmenite is the most abundant main heavy mineral, followed by rutile, pseudorutile (altered ilmenite) and zircon [1]. Some HMS deposits contain low amounts of rare earth minerals like monazite and xenotime. In Senegal, the great coast is $100 \mathrm{~km}$ long and $5 \mathrm{~km}$ wide along the north coast. It is operated by the company Grande Côte Operation (GCO). This deposit belongs to the Senegal-Mauritanian basin which is a pericratonic basin surrounded by the paleoproterozoic to Hercynian age formations of the West African Craton. This study aims to determine the complete mineralogical composition of the heavy mineral sands of the great coast of Senegal. The innovative Qemscan technique is used to determine the chemical variability of the different minerals in the HMS of Senegal. Scanning electron microscopy (SEM) observations provide a complement to QEMSCAN analyses and allow identifying the different textural relationships between the main minerals, mainly titanium oxides and zircon. The study of mineralogical variations is important and allows us to better understand the difficulties in reaching the chemical specifications of heavy mineral concentrates.

\section{Geological Settings}

The study area belongs to the Senegal-Mauritania-Guinean basin that covers from north to south: western Mauritania, most of Senegal, Gambia, Guinea-Conakry and Guinea-Bissau, where the name of MSGBC basin [2]. It is the most western and most extensive of Meso-Cenozoic basins located along the Atlantic margin of Africa. The Quaternary which constitutes the major part of the outcrops of the basin includes marine, continental and volcanic formations. It is subdivided into different periods marked by alternating repetitive episodes of humid climate during the marine transgression and arid climate during the marine regression.

Periods of transgression have allowed the deposition of shell sand, clays and ilmenite sand along the coasts. The periods of regression and arid climate are marked by the establishment of vast spreading of dune sands forming large ergs of "Red Dunes". During these periods, the rivers cut their courses in search of balance, thus forming fossil valleys later covered by ergs of red dunes. These repetitive episodes of marine transgression and regression have shaped the landscape.

The geomorphology of the study area is thus marked by three continental and marine dune systems (Figure 1). The continental Ogolian red dune system implemented during the arid Ogolian period (20,000 to 12,000 years BP) and fixed by a trees savannah. The Tafolian dune system (4000 to 2000 years BP), also called yellow dunes, is semi-fixed by vegetation with variable extension. The sub actual to actual dune system (1700 years at present) also known as coastal sand dunes established in favour episodes' marine transgressions is mobile and form a wide band from several meters to several hundred meters [3] [4]. 


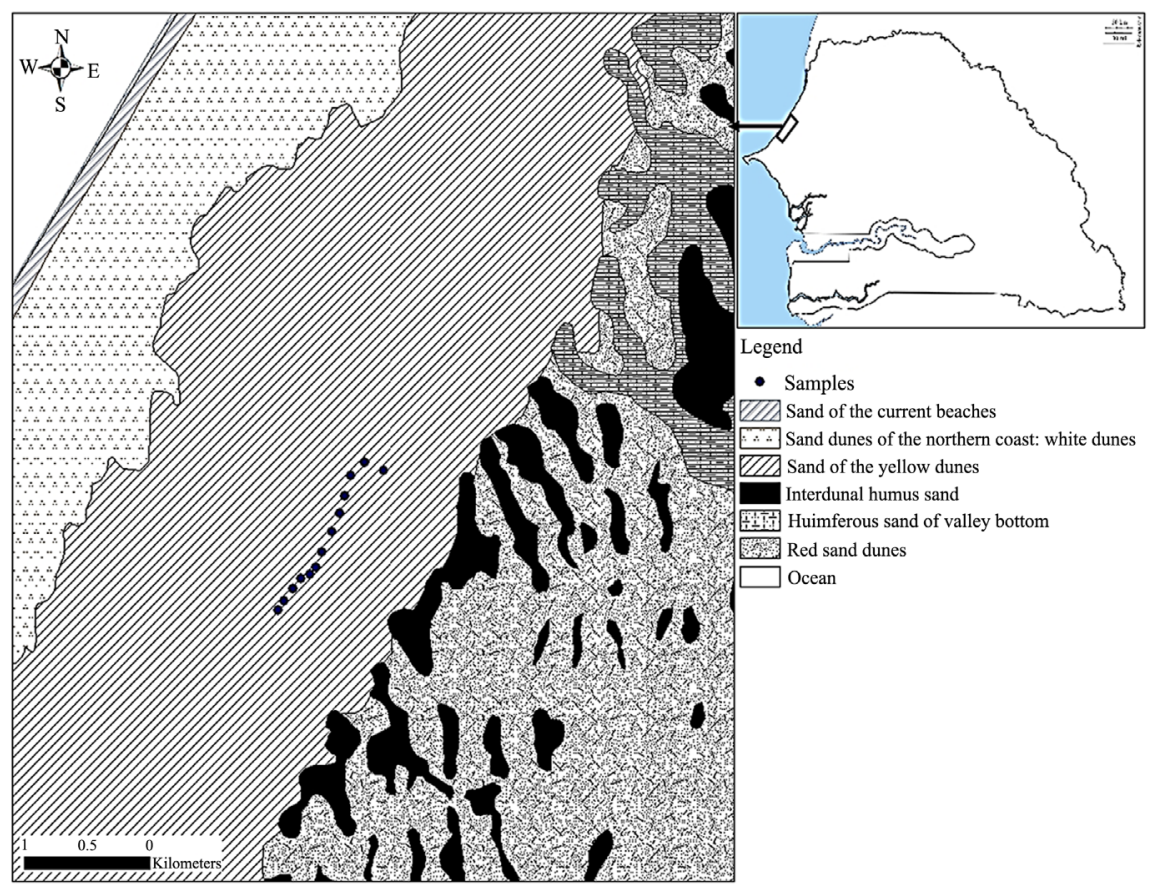

Figure 1. Geological map of the study area modified from [2].

The Senegalese great coast deposit, which is one of the largest in the world, extends over a strip $100 \mathrm{~km}$ long and $5 \mathrm{~km}$ wide. The exploitation of GCO is mainly located on the part of the yellow dunes which concentrate most of the deposit. However, heavy mineral deposits are also found in the Ogolian erg dunes and the current sand dunes (Figure 1 and Figure 2).

The deposit also presents traces of the wet period and marine transgression of the Nouakchottien (7000 to 4200 years BP) where the sea enters the valleys and deposit sand clays associated or not with shells and peat (Figure 2). In some places, heavy mineral deposits can reach $10 \%$ of the raw sand. Iron-titanium rich grains from the sands of senegalese great coast have already been the subject of a textural, magnetic and geochemical study by Allouc et al., 1999 [5], which made it possible to have an idea of the different possible sources. The results of this study showed that in the whole population, the grains are sub-rounded to subangular. The grains are most often grayish white with often a start of leucoxene alteration on their border or along small cracks. A few individuals are completely transformed into leucoxene. The grains showed a great variation in magnetic susceptibility linked to their difference in chemical composition and to the different degrees of deterioration. The geochemical analysis showed a strong affinity with the iron-titanium train of the "continental terminal" formation for the Iron-titanium minerals of the great coast. The authors therefore identified two possible sources: contributions from Mauritania in favor of the great N-S drift and of the terminal containment. The source rocks seem to be the metamorphic rocks of a basic character probably deriving from the Mauritanide orogen and the Reguibat uplift. 


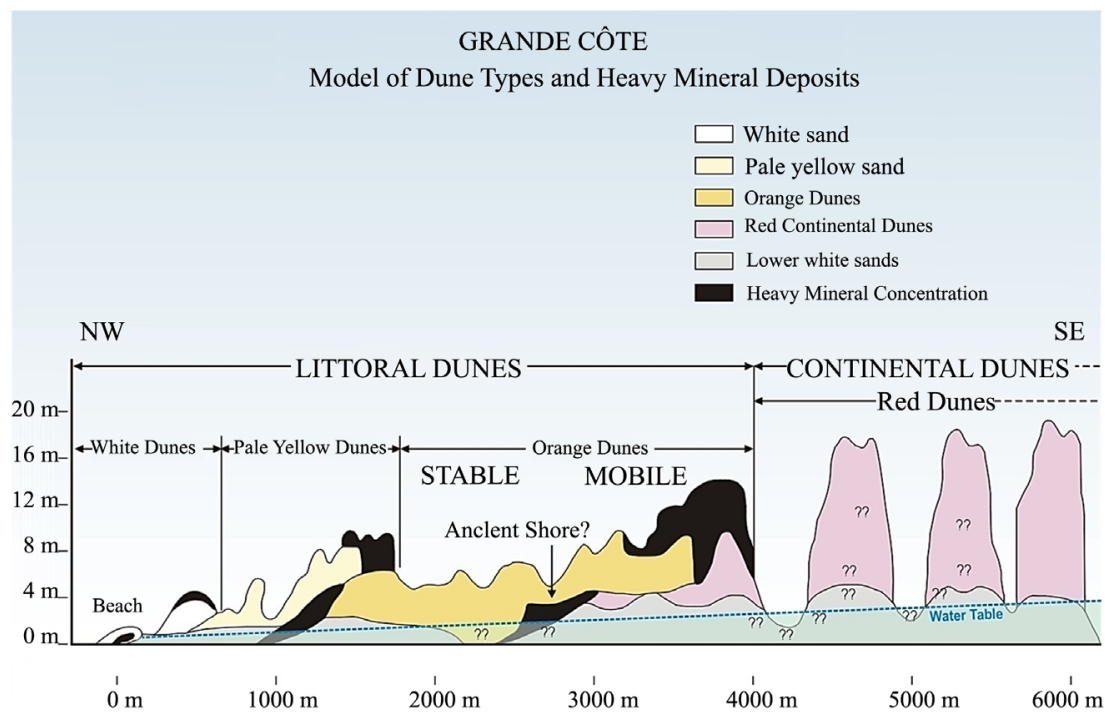

Figure 2. Model of Dune types and heavy Mineral deposits (source: GCOmine DFS report-MDL 2010).

\section{Materials and Methods}

\subsection{Heavy Mineral Concentration at GCO}

The heavy mineral sand is extracted by a floating dredge which sucks the ore from the front of the dredging basin and sends it as a pulp to the wet concentrate plant (WCP) (Figure 3). After washing and screening to remove possible rock fragments, the mineralized sand mainly composed of quartz is treated by a battery of cyclones which will remove very fine particles (clayey). The coarse product is then sent to a series of spirals which separate the heavy minerals (ilmenite, zircon, leucoxene, rutile and other dense minerals) and the gangue essentially composed of silicate minerals such as garnet, staurolite, quartz, epidote, kyanite, and others). The obtained product is a concentrate of heavy minerals (HMC). 13 HMC samples were collected from the dredge at different operating times.

The HMC (heavy mineral concentrate) are then treated by a series of magnetic and electrostatic separation to produce zircon, ilmenite, leucoxene and rutile concentrates. Figure 4 summarizes the different products obtanied.

HMC are first treated by high intensity magnetic separation to extract magnetic minerals such as ilmenite. The non-magnetic minerals obtanied from this separation will undergo gravity separation in order to purify the product and remove the remaining gangue min erals such as quartz. This step produces rejects called WMT (Wet Mill Tails) and a heavy mineral concentrate which undergo, after drying, an electrostatic separation to concentrate the zircon, which is non-conductive, and the minerals of rutile and leucoxene which are conductive. Finally, leucoxene and rutile products are separated by magnetism because minerals forming leucoxene are more magnetic. It should be noted that at each stage of treatment, the products are reprocessed several times to generate pure concentrates and therefore tailings which will either be recycled or rejected as sterile. 


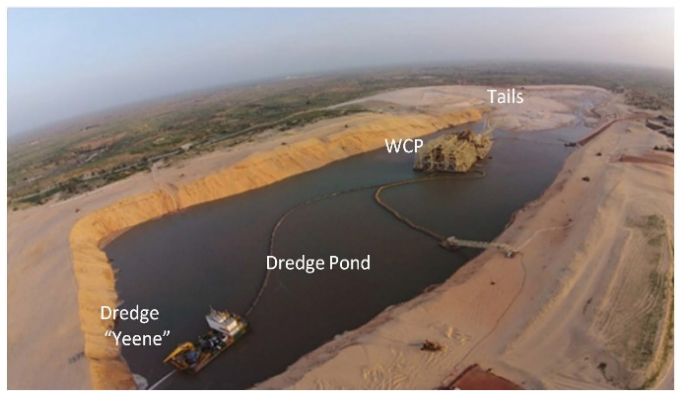

Figure 3. Dredging through the dune system (GCO image).

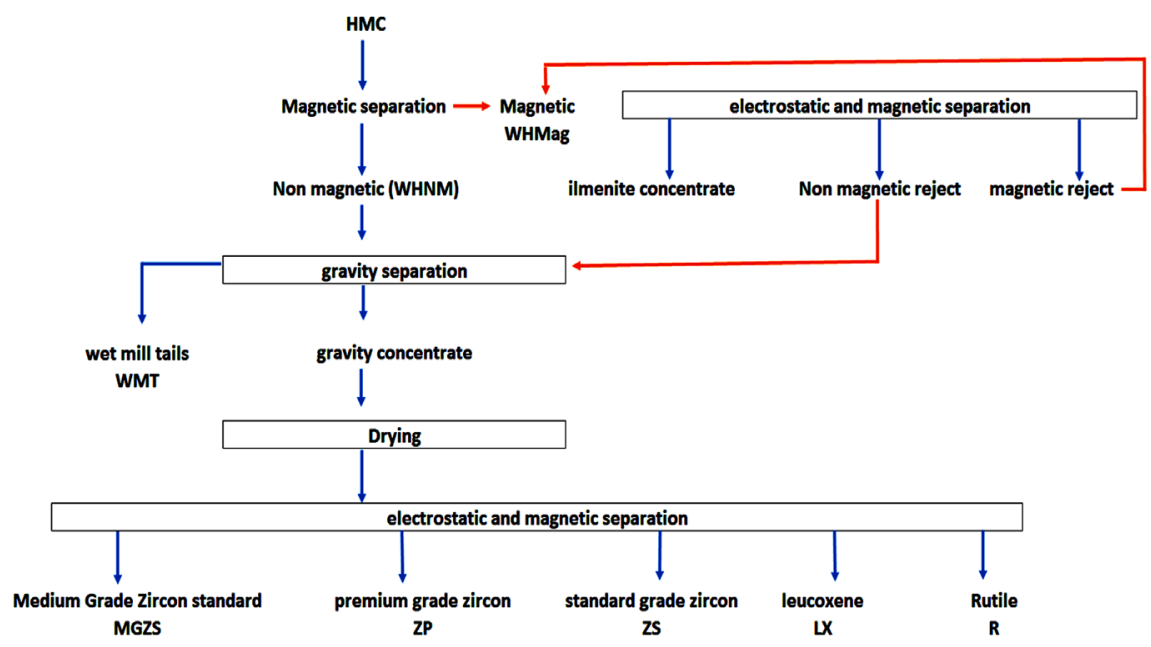

Figure 4. Simplified flowsheet of heavy minerals processing circuit at GCO.

For our study, we selected the following products from the plant: ilmenite concentrates (IL1 and IL2), Wet Mill Tail or WMT, a concentrate of very pure premium zircon (ZP), a standard zircon concentrate (ZS), medium grade (MGZS), leucoxene (LX), rutile (R). To account for mineralogical variations in the deposit, samples were collected weekly over a three-month period.

\subsection{Analytical Procedure}

\section{Qemscan}

The collected samples are mounted in a polished section and then analyzed with QEMSCAN. It is an automated technique for the fast characterization of mineral and non-crystalline phases, on polished sections, by means of SEM (Scanning Electron Microscope)-EDS (Energy Dispersive Spectrometer). QEMSCAN analyses for this project were carried out at the ERAMET Ideas mineralogical service, using a FEI Quanta 650F SEM platform with two Bruker Xflash $30 \mathrm{~mm}$ silicon drift energy dispersive X-ray detectors. The software used included iMeasure v. 5.4 for the data acquisition and iDiscover v. 5.4 for the spectral interpretation and data processing. The "BMA (Bulk Mineral Analyses) measurement mode" was used for mineralogical characterizations of samples with collecting X-ray data every $2.5 \mu \mathrm{m}$ across the polished sample surfaces, with $\mathrm{X}$-rays acquired at 2000 total X-ray counts per spectrum. The "Field Image 
measurement mode" was also used to perform mineral mapping of the samples in order to observe alteration textures on a micron scale.

The spectrum obtained after analysis of each point within the fields is associated with an experimental EDS spectrum using the system software. From this simulated spectrum, the software determines the relative mass concentrations of the elements present. It is thus necessary to have to fill in the database with information relating to chemical concentrations. At Eramet Ideas, this information comes from microprobe measurements. It is an innovative technology increasingly used in the rapid determination of the mineralogical compositions of sand samples [6] [7] [8] [9].

\section{Scanning Electron Microscopy}

Backscattered electron (BSE) images of the minerals concentrates were taken using a JEOL JSM 6360LV scanning electron microscope equipped with a silicon drift detector analysis system at the Geosciences Environment Toulouse (GET) laboratory in Toulouse. The compositions of grains were determined using wavelength dispersive spectrometers in the GET laboratory. The operating conditions were: an acceleration voltage of $15 \mathrm{kV}$, a beam current of $20 \mathrm{nA}$ and a beam diameter of $3 \mu \mathrm{m}$ for all the elements. Standards were: $\mathrm{NdPO}_{4}(\mathrm{Nd})$, $\mathrm{SmPO}_{4}(\mathrm{Sm}), \mathrm{GdPO}_{4}(\mathrm{Gd}), \mathrm{PrPO}_{1}(\mathrm{Pr}), \mathrm{DyPO}_{4}$ (Dy), Woll (Ca, Si), $\mathrm{LaPO}_{4}$ (La, $\mathrm{P}), \mathrm{CePO}_{4}(\mathrm{Ce}), \mathrm{YPO}_{4}(\mathrm{Y}), \mathrm{PbJMM}(\mathrm{Pb}), \mathrm{ThO}_{2}(\mathrm{Th}), \mathrm{UO} 2(\mathrm{U})$.

SEM images then allow characterising the intra-grain textures, such as chemical zoning or altered zones, and the inter-grain textural relationships, such as inclusions, intergrowth or overgrowths [10]. Some quantitative measurements are possible with SEM to unravel the chemical composition of a grain unidentified by Qemscan. The detection limit of the chemical elements by X-rays is 1000 ppm.

\section{Results}

\subsection{Minerals Distribution and Associations}

Table 1 shows the different results of the Qemscan analyses of the HMC samples.

The Qemscan analyses allowed establishing particle maps of the HMC samples (Figure 5(a)), thus giving their chemical and mineralogical composition. Figure 5(b) shows that the mineral concentration is heterogeneous with concentrations of heavy minerals and waste rock which strongly vary. HMC mainly consists in titanium oxides $78.51 \%$, zircon $11.27 \%$ and other minerals $10.08 \%$ which includes all the sterile or gangue minerals. These sterile minerals are essentially constituted by silicate and alumino silicates minerals. Rare earth minerals have a very low concentration. Qemscan analysis thus detected the presence of monazite on all samples of HMC, florencite and crandallite only on certain samples.

Table 2 shows the mineralogical composition of the various concentrates produced with GCO. The ilmenite, leucoxene and rutile products therefore 
Table 1. HMC minerals composition (wt\%).

\begin{tabular}{|c|c|c|c|c|c|c|c|c|c|c|c|c|c|c|}
\hline Minerals & HMC-1 & HMC-2 & HMC-3 & HMC-4 & HMC-5 & HMC-6 & HMC-7 & HMC-8 & HMC-9 & HMC-10 & HMC-11 & HMC-12 & HMC-13 & $\begin{array}{l}\text { Avg } \\
\text { HMC }\end{array}$ \\
\hline Monazite & 0.02 & 0.03 & 0.01 & 0.01 & 0.02 & 0.03 & 0.13 & 0.06 & 0.04 & 0.02 & 0.02 & 0.02 & 0.06 & 0.04 \\
\hline Crandallite & 0.00 & 0.01 & 0.00 & 0.00 & 0.01 & 0.00 & 0.00 & 0.02 & 0.00 & 0.00 & 0.01 & 0.00 & 0.00 & 0.00 \\
\hline Florencite & 0.00 & 0.05 & 0.00 & 0.00 & 0.00 & 0.01 & 0.01 & 0.03 & 0.00 & 0.00 & 0.00 & 0.00 & 0.01 & 0.01 \\
\hline Zircon & 10.68 & 11.47 & 13.04 & 10.84 & 16.02 & 10.45 & 10.06 & 7.82 & 11.05 & 10.30 & 11.68 & 12.24 & 10.86 & 11.27 \\
\hline Ilmenite & 22.09 & 25.33 & 21.91 & 22.16 & 22.99 & 24.56 & 20.97 & 19.49 & 24.67 & 14.57 & 22.34 & 19.66 & 21.61 & 21.72 \\
\hline Pseudorutile & 50.71 & 52.55 & 52.46 & 53.01 & 49.32 & 55.05 & 52.78 & 48.72 & 54.54 & 63.68 & 51.58 & 51.74 & 50.39 & 52.81 \\
\hline Anatase & 1.01 & 0.87 & 1.31 & 1.05 & 1.24 & 1.11 & 1.13 & 1.29 & 0.96 & 1.53 & 1.09 & 1.36 & 1.12 & 1.16 \\
\hline Rutile & 2.52 & 2.32 & 2.43 & 2.47 & 2.54 & 2.71 & 2.13 & 2.52 & 2.19 & 3.22 & 2.45 & 2.99 & 2.83 & 2.56 \\
\hline $\begin{array}{l}\text { Other Ti } \\
\text { Oxides }\end{array}$ & 0.22 & 0.21 & 0.33 & 0.24 & 0.37 & 0.21 & 0.36 & 0.16 & 0.30 & 0.24 & 0.22 & 0.20 & 0.24 & 0.25 \\
\hline Phyllosilicates & 0.23 & 0.20 & 0.41 & 0.17 & 0.29 & 0.14 & 0.44 & 0.27 & 0.29 & 0.24 & 0.20 & 0.25 & 0.22 & 0.26 \\
\hline Quartz & 8.19 & 4.28 & 5.68 & 6.36 & 4.43 & 3.08 & 7.24 & 14.38 & 2.93 & 3.80 & 7.04 & 6.40 & 8.73 & 6.35 \\
\hline Garnet & 0.24 & 0.22 & 0.08 & 0.20 & 0.12 & 0.20 & 0.13 & 0.34 & 0.07 & 0.15 & 0.34 & 0.43 & 0.28 & 0.22 \\
\hline Spinels & 0.07 & 0.12 & 0.13 & 0.10 & 0.12 & 0.07 & 0.06 & 0.14 & 0.12 & 0.10 & 0.03 & 0.21 & 0.03 & 0.10 \\
\hline Fe-Cr oxides & 0.21 & 0.02 & 0.03 & 0.03 & 0.06 & 0.01 & 0.03 & 0.05 & 0.03 & 0.04 & 0.08 & 0.07 & 0.13 & 0.06 \\
\hline Silicate Al & 2.74 & 2.07 & 1.37 & 2.87 & 1.69 & 1.93 & 2.23 & 3.70 & 1.15 & 1.61 & 2.15 & 3.40 & 2.57 & 2.27 \\
\hline $\mathrm{Al}$ minerals & 0.07 & 0.05 & 0.03 & 0.07 & 0.01 & 0.06 & 0.19 & 0.12 & 0.37 & 0.17 & 0.08 & 0.14 & 0.08 & 0.11 \\
\hline Other Silicates & 0.25 & 0.06 & 0.04 & 0.21 & 0.16 & 0.17 & 0.13 & 0.20 & 0.08 & 0.01 & 0.21 & 0.33 & 0.18 & 0.16 \\
\hline $\begin{array}{c}\text { Other } \\
\text { Minerals }\end{array}$ & 0.01 & 0.00 & 0.00 & 0.00 & 0.00 & 0.00 & 0.01 & 0.01 & 0.00 & 0.00 & 0.01 & 0.00 & 0.02 & 0.01 \\
\hline Unidentified & 0.33 & 0.13 & 0.72 & 0.22 & 0.61 & 0.20 & 1.97 & 0.70 & 1.18 & 0.31 & 0.17 & 0.55 & 0.18 & 0.56 \\
\hline Zircon & 10.68 & 11.47 & 13.04 & 10.84 & 16.02 & 10.45 & 10.06 & 7.82 & 11.05 & 10.30 & 11.68 & 12.24 & 10.86 & 11.27 \\
\hline Titane oxides & 76.55 & 81.29 & 78.46 & 78.93 & 76.47 & 83.64 & 77.38 & 72.17 & 82.66 & 83.23 & 77.68 & 75.94 & 76.19 & 78.51 \\
\hline REE & 0.02 & 0.08 & 0.02 & 0.01 & 0.02 & 0.04 & 0.14 & 0.11 & 0.05 & 0.03 & 0.03 & 0.02 & 0.07 & 0.05 \\
\hline $\begin{array}{l}\text { Others } \\
\text { minerals }\end{array}$ & 12.34 & 7.16 & 8.49 & 10.22 & 7.49 & 5.86 & 12.42 & 19.90 & 6.23 & 6.43 & 10.32 & 11.78 & 12.42 & 10.08 \\
\hline Total & 99.59 & 100.00 & 100.00 & 100.00 & 99.99 & 100.00 & 100.00 & 100.00 & 99.99 & 99.99 & 99.70 & 99.99 & 99.54 & 99.91 \\
\hline
\end{tabular}

Table 2. Minerals composition in concentrates (wt\%).

\begin{tabular}{ccccccccccc}
\hline Minerals (wt\%) & HMC & IL1 & IL2 & WMT & ZP & ZS & MGZS & LX & R \\
\hline Apatite & 0.002 & 0.000 & 0.000 & 0.003 & 0.018 & 0.011 & 0.006 & 0.001 & 0.001 \\
Monazite & 0.036 & 0.004 & 0.017 & 0.025 & 0.022 & 0.013 & 0.528 & 0.017 & 0.018 \\
Crandallite & 0.004 & 0.000 & 0.000 & 0.034 & 0.001 & 0.003 & 0.002 & 0.004 & 0.004 \\
Florencite & 0.009 & 0.000 & 0.000 & 0.081 & 0.001 & 0.009 & 0.047 & 0.031 & 0.009 \\
Xenotime & 0.000 & 0.000 & 0.000 & 0.000 & 0.002 & 0.005 & 0.007 & 0.001 & 0.003 \\
Thorite & 0.000 & 0.000 & 0.000 & 0.003 & 0.000 & 0.000 & 0.015 & 0.001 & 0.001 \\
Zircon & 11.269 & 0.081 & 0.233 & 1.641 & 99.207 & 98.978 & 33.657 & 0.637 & 0.982 \\
\hline
\end{tabular}




\section{Continued}

\begin{tabular}{ccccccccccc}
\hline Titane oxides & 78.507 & 99.262 & 98.365 & 11.456 & 0.106 & 0.167 & 55.601 & 98.224 & 98.189 \\
Quartz & 6.350 & 0.086 & 0.139 & 70.700 & 0.046 & 0.149 & 0.876 & 0.255 & 0.194 \\
Grenats & 0.240 & 0.018 & 0.054 & 0.286 & 0.002 & 0.007 & 0.706 & 0.011 & 0.001 \\
Spinels & 0.070 & 0.084 & 0.262 & 0.057 & 0.000 & 0.002 & 0.480 & 0.032 & 0.000 \\
Others minerals & 2.860 & 0.372 & 0.764 & 15.326 & 0.440 & 0.394 & 7.307 & 0.503 & 0.410 \\
Non identified & 0.560 & 0.092 & 0.166 & 0.387 & 0.157 & 0.262 & 0.770 & 0.285 & 0.188 \\
total & 100 & 100 & 100 & 100 & 100 & 100 & 100 & 100 & 100 \\
\hline
\end{tabular}

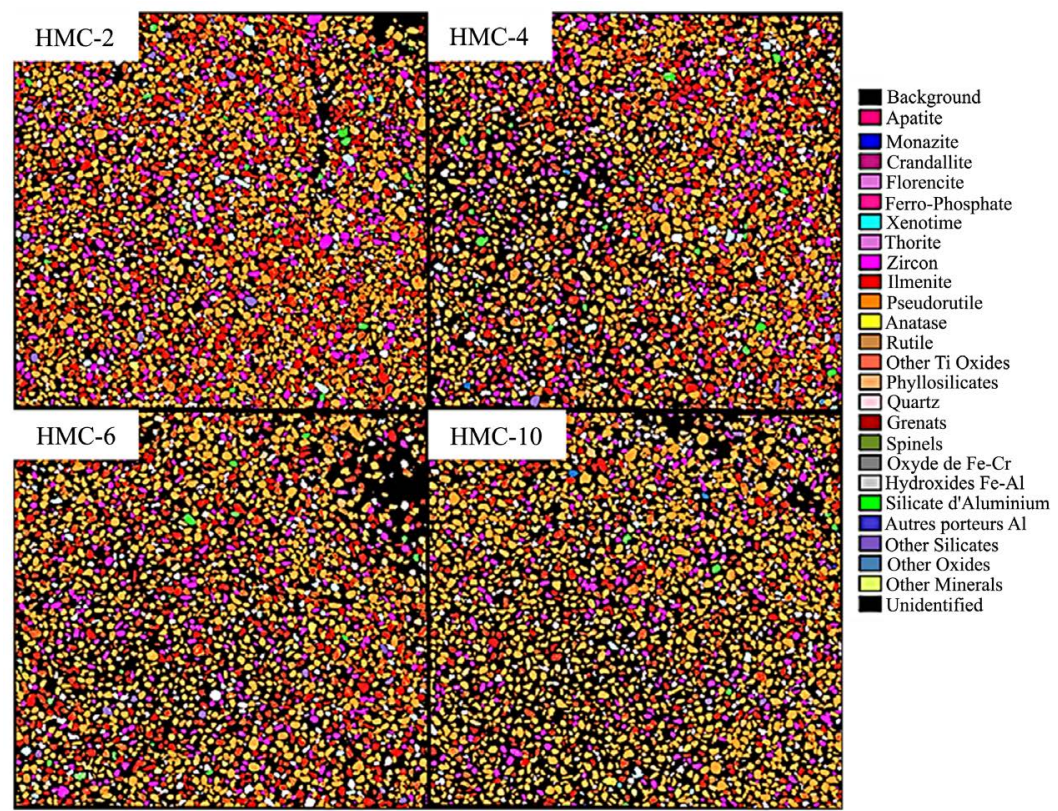

(a)

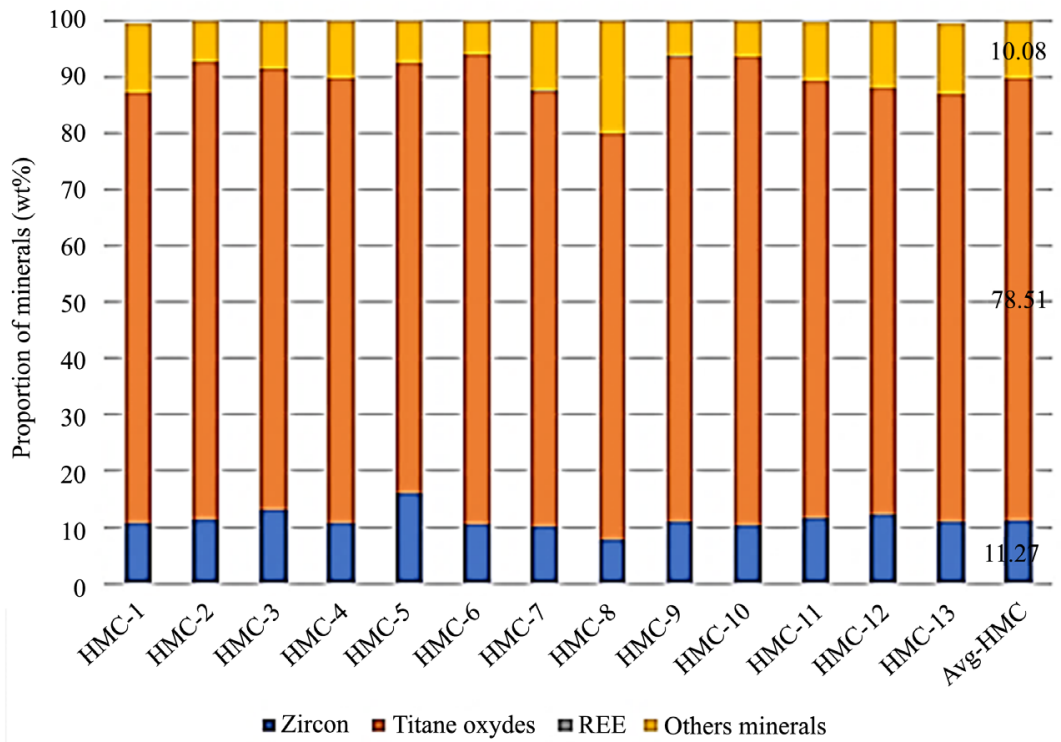

(b)

Figure 5. (a) QEMSCAN field map of particles in HMC sample; (b) Minerals proportion in HMC sample. 
consist mainly of titanium oxide at more than $98 \%$, the zircon concentrates are almost pure at more than 99\% (Figure 6). Premium zircon and standard zircon concentrates contain $99 \%$ zircon. The difference between these two concentrates is their iron content. The WMT product, which is a production reject, consists mainly of sterile minerals with, however, a certain concentration of titanium oxide (11\%). The mineral separation will thus generate a low quality zircon concentrate called Medium Grade Zircon Standard (MGZS) which also contains a high concentration of titanium oxides and non-negligible concentrations of monazite (Table 2). Monazite is a non-electrically conductive and paramagnetic

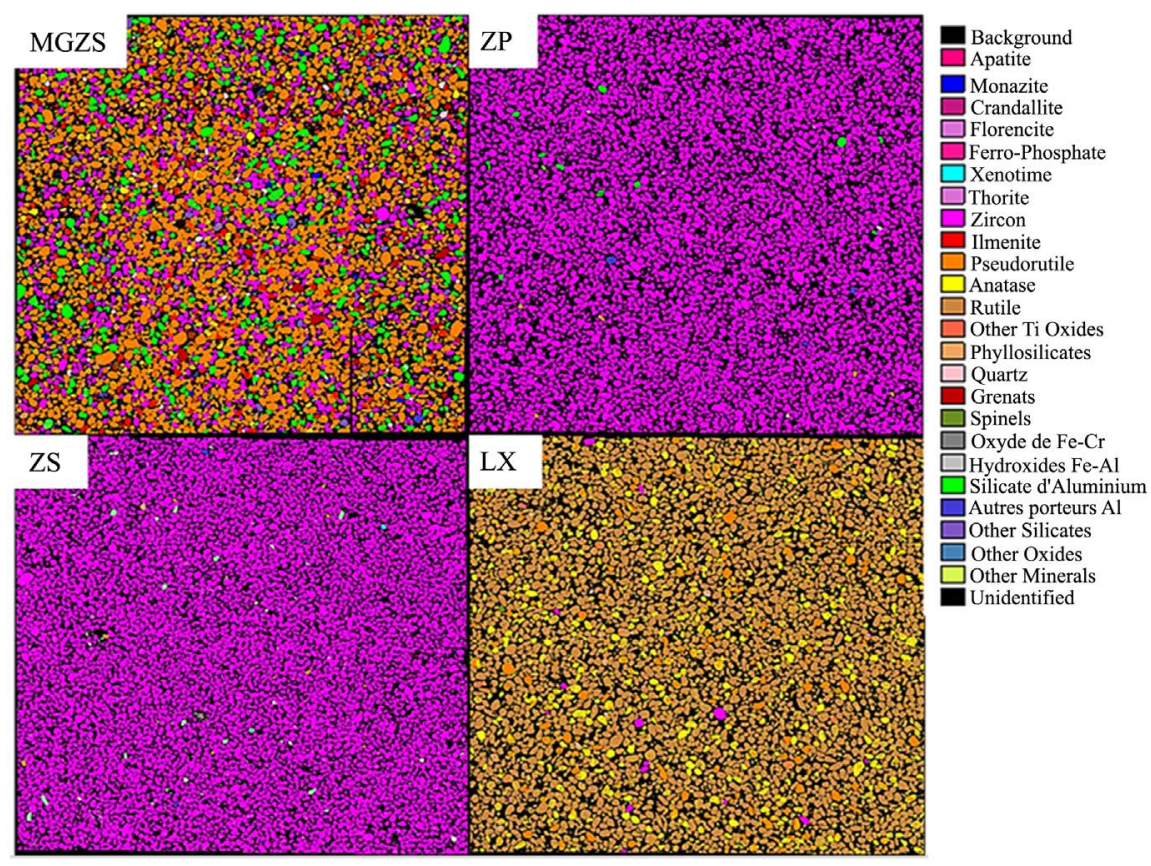

(a)

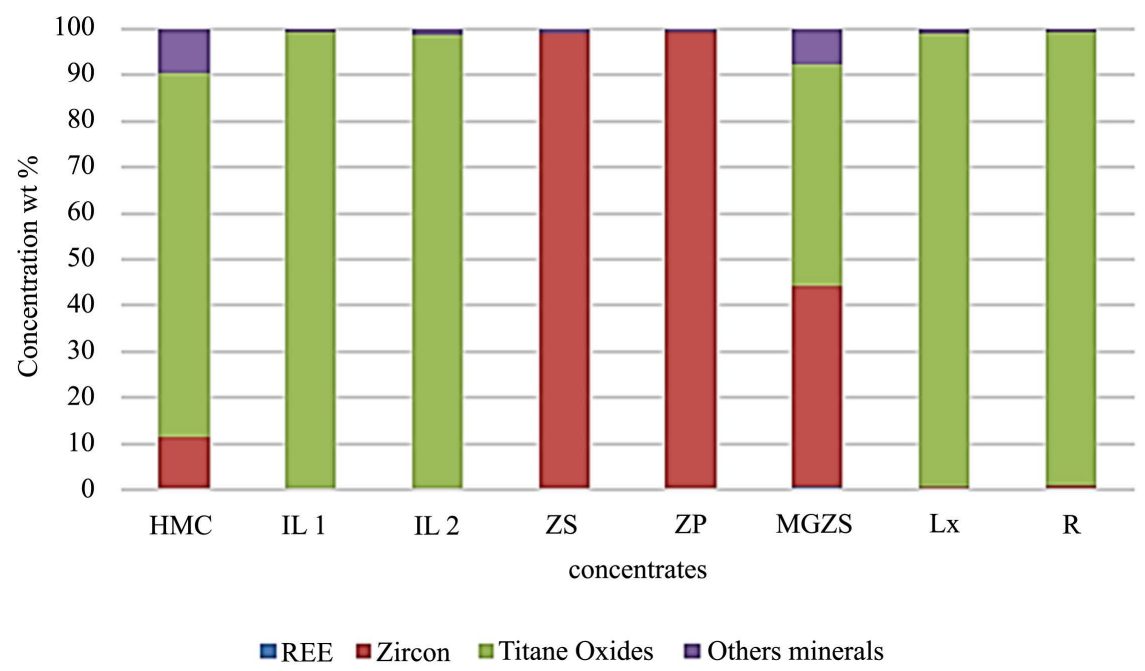

(b)

Figure 6. (a) QEMSCAN field map of particles in concentrates sample; (b) Minerals proportion in concentrates sample. 
mineral. This explains why it is found in the MGZS product. This MGZS contain concentrations of zircon (33\%) and titanium oxide (55\%) which today justified its marketing as a concentrate of medium-grade zircons. We can also note low concentrations of phosphate minerals such as monazite, crandallite, florencite. These minerals also contain rare earth elements.

The mineral association diagram (Figure 7) is useful to evaluate the liberation potential of impurities in the minerals. The $\mathrm{Y}$-axis (labelled as transitions) represents the relative amounts of mineral phases that are adjacent to the mineral given in X-axis. The "Background" represents the amount of pixels adjacent to other pixel of the same color, i.e., it reflects mineral phase continuity through the Qemscan color map. As an example, in the MGZS product (Figure 7), more than $90 \%$ of the zircon pixels are adjacent to other zircon pixels, which mean that zircon is quite pure and is unlikely to host other mineral phases. This also means that only a very small surface percentage of all zircons is covered or coated by other phases. The few mineral phases adjacent to (or included in) zircon are pseudorutile, phyllosilicates and phosphates.

Figure 7 presents the mineral association diagram of the MGZS concentrate. As a reminder, this product is obtained after recovery of titanium oxide and zircon minerals. It therefore concentrates the minerals with impurities. Its analysis reveals that ilmenite is generally associated with pseudorutile, which reflects the fact that the pure ilmenite particles are mostly recovered in the ilmenite concentrates. In turn, pseudorutile is generally associated with anatase in addition to ilmenite, and anatase has a strong affinity for rutile. We also note a strong mineral association between aluminium iron oxides and aluminium silicates but also zircon and rutiles in these sterile minerals.

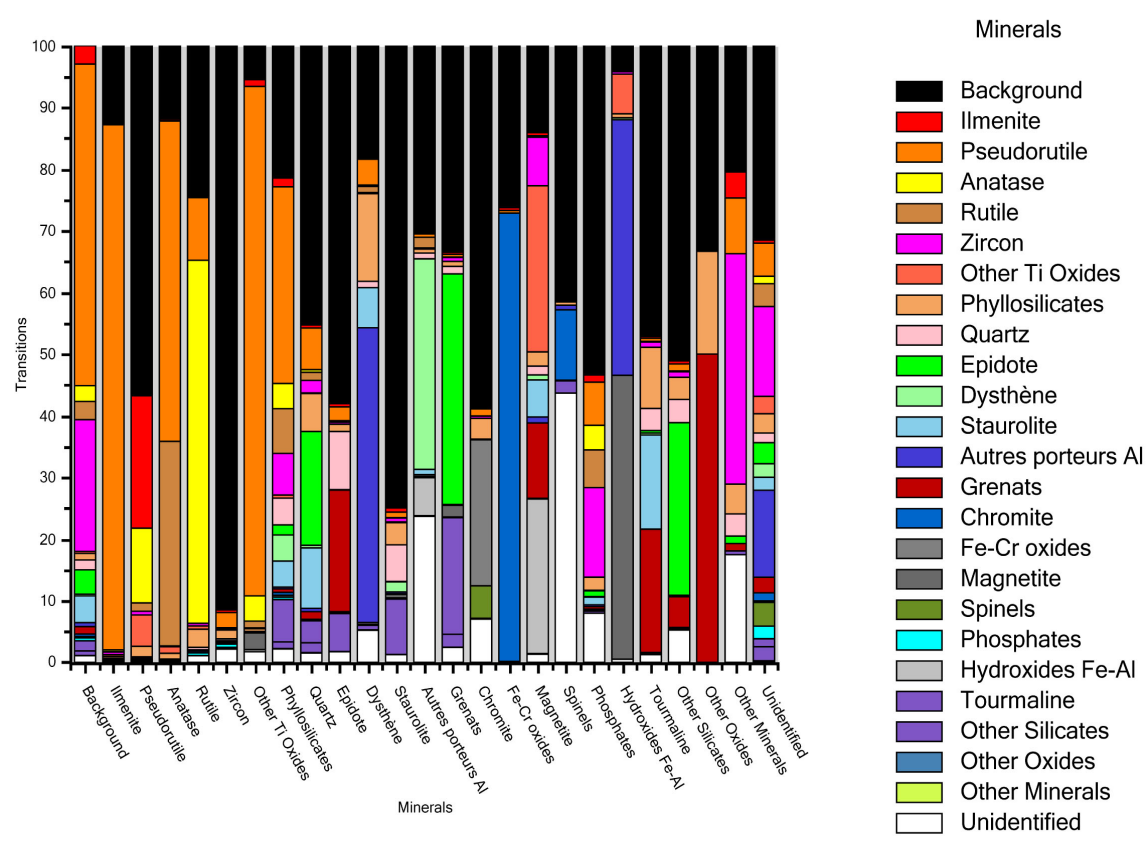

Figure 7. Mineral association. 


\subsection{Scanning Electron Microscope}

The Qemscan images offer an easy way to target mineral particles of interest for SEM observations (Figure 8). The Qemscan particle map first allows identifying the chemical composition of each grain.

The work of Delaporte et al. (2019) [11] in the Senegalese HMS has shown the difference in BSE level (grey intensity) between primary $\mathrm{TiO}_{2}$ particles (rutile or anatase) and secondary grains resulting from intense alteration [11] (Figure 9).

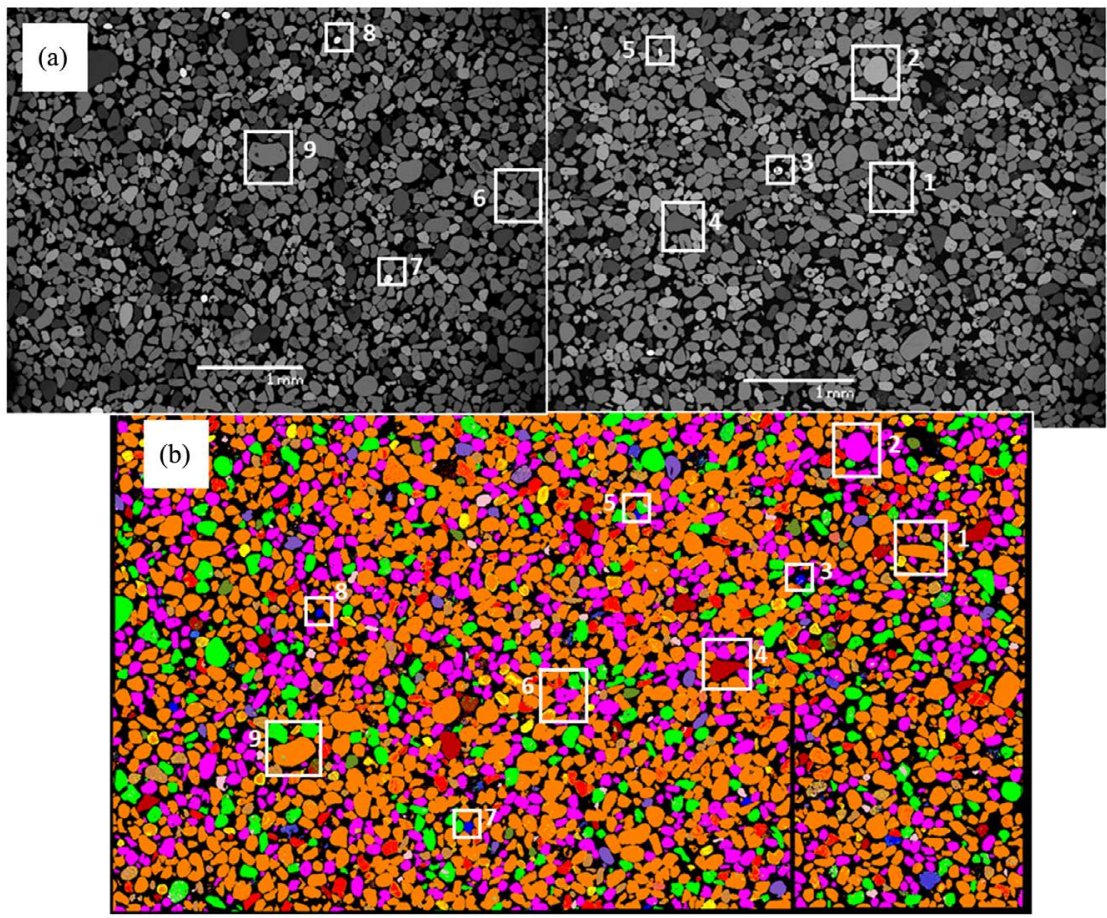

Figure 8. Qemscan and SEM image correlation: (a) BSE image; (b) Qemscan particle map showing the chemical concentrations of the particles. $(1,4,9)$ Titanium oxide; (2) and (6) zircon, $(3,8,7)$ monazite; (4) anatase or rutile; (5) monazite.

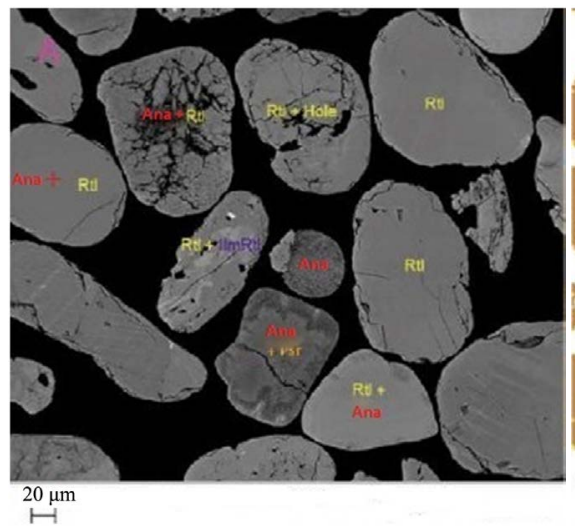

(a)

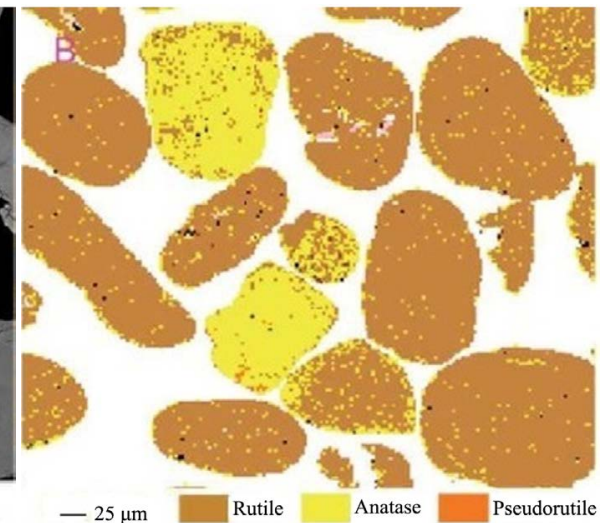

(b)

Figure 9. BSE image (a) of an area of the leucoxene product sample and mineralogical interpretation, (b) of this area by QEMSCAN analysis. Rtl: rutile; Ana: microcrystalline anatase, Psr pseudorutile altered; IlmRtl: ilmenorutile [11]. 
A comparison of Qemscan and SEM images in a LX sample reveals that the rutile and anatase crystals defined as such by Qemscan turn out to be texturally complex. It is possible to observe the different alteration textures, porosities, and fractures found in these grains. One anatase grain is strongly porous and fractures, whereas another shows a distinct alteration halo. Rutile may show oscillatory zoning (lower right corner) or patchy zoning (grain in the middle).

BSE images of leucoxene particles (altered ilmenite) show a marked zonation of some grains (Figure 10(a)). Their chemical composition shows in addition to
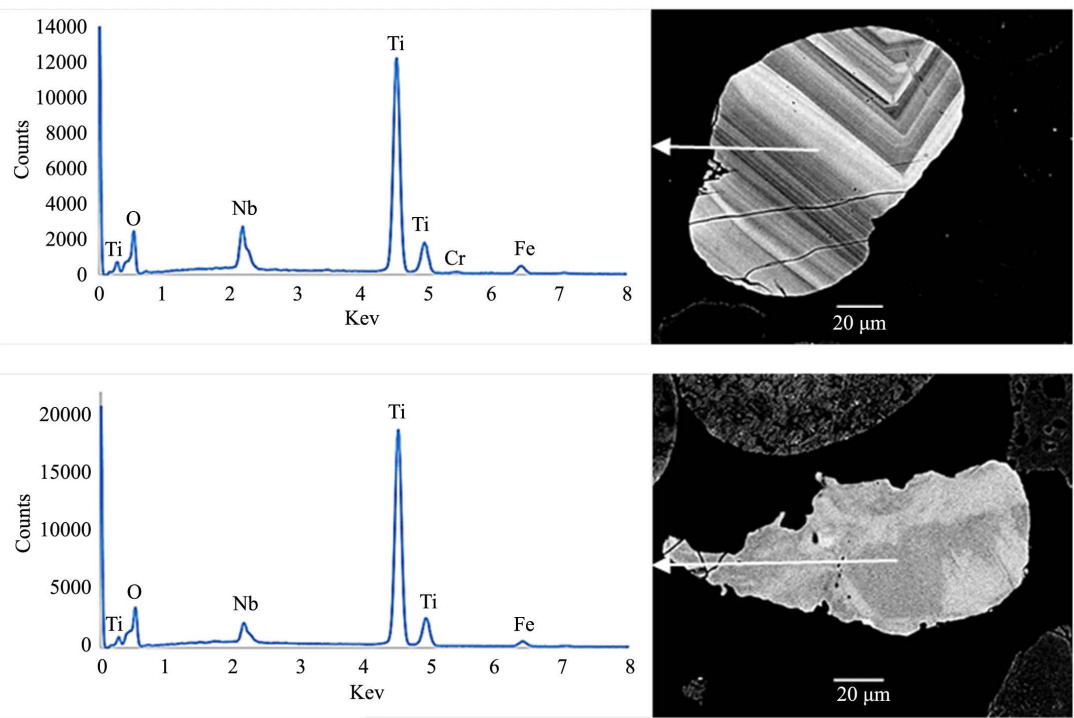

(a)
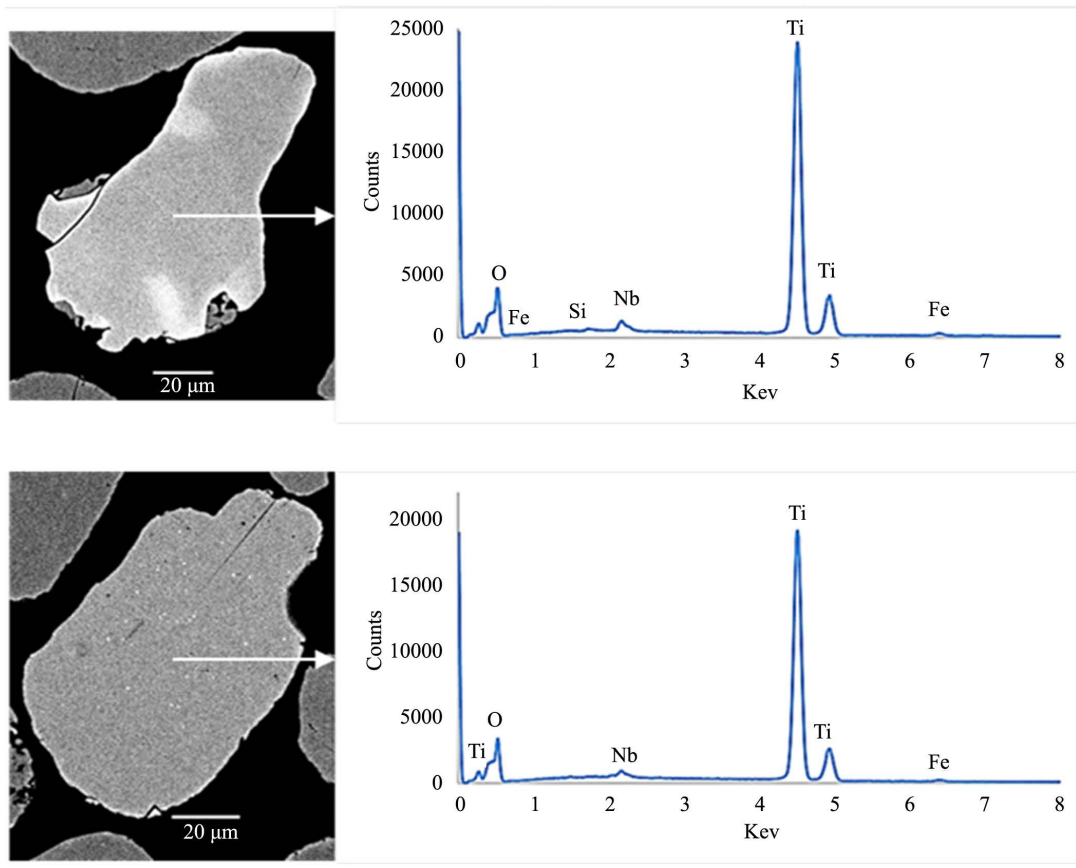

(b)

Figure 10. BSE image and spectre of titanium oxides minerals (a) leucoxene grains; (b) rutile grains. 
their titanium iron content, a certain concentration of niobium. Figure 10(b) also shows the composition of the grains of the rutile grains consisting essentially of titanium but with a very low proportion of niobium.

Figure 11 shows the numerous inclusions or outgrowths of minerals observed under a SEM. We notice inclusions of heavy elements in other heavy minerals but also inclusions of gangue minerals in heavy minerals.

Rare earth phosphates like monazite and xenotime are found as inclusion in zircon (Figure 11(a) \& Figure 11(b)). The monazite content is not negligible in MGZS product. Zircon particles also contain thorianite and barites inclusions (Figure 11(c) \& Figure 11(d)). Lead sulfides such as galena are also found in inclusion in zircon and also in titanium oxides such as rutile (Figure 11(e) \& Figure 11(f)).
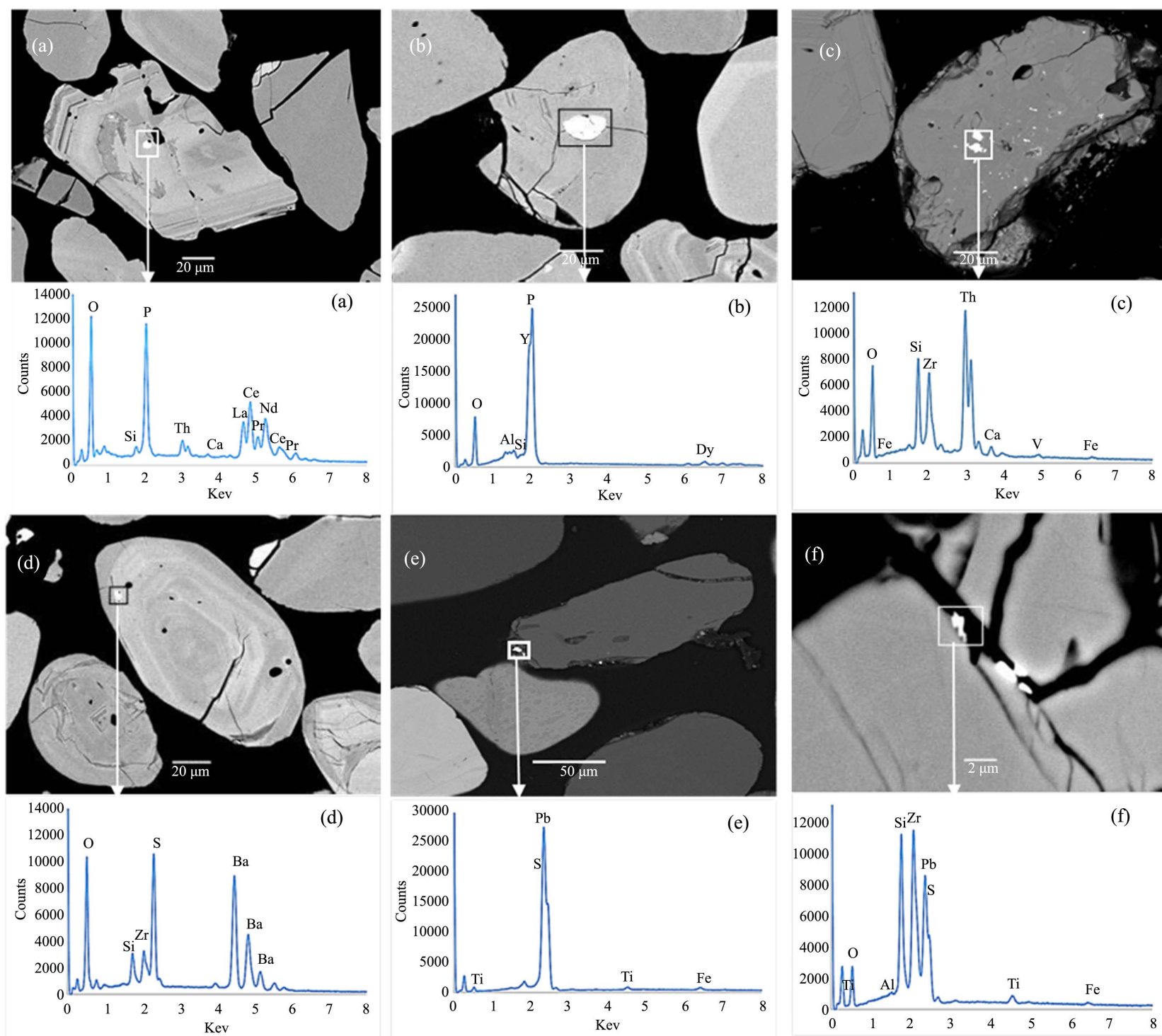

Figure 11. BSE image of some particles inclusions. (a) Monazite inclusion in zircon grain; (b) xenotime in zircon (c) thorianite inclusion in zircon grain; (d) barite in zircon; (e) galena in rutile; (f) galena in zircon. 


\section{Discussion}

QEMSCAN technology enable rapid analysis of thousands of grains within hours. The other advantage of the Qemscan software is that not only minerals or phases can be identified and listed but also that textural relationships can be regarded in grade detail over, if available, a representative sample. These textural relationships could be verified with a scanning electron microscope (Figure 9).

The variation in the chemical composition of HMC is linked to the heterogeneity of the deposit but also to the operating conditions at the dredge level.

All the minerals present in HMC are constituents of magmatic and metamorphic rocks. Several studies have already shown that high gradient metamorphic rocks as well as igneous rocks are the main sources of heavy minerals in beach sands [12]. The processes to the formation of placer deposits on the beach generally begin inland and end at the coast, the source rocks (magmatic or metamorphic) being eroded and then transported by streams and rivers to the coast where sediments are deposited in various coastal environments [12] [13]. Heavy minerals are very resistant to erosion and transport to the coast. Heavy mineral deposits include a set of minerals (Table 3), the main ones of which are most often minerals containing titanium (ilmenite, rutile and pseudorutile) zircon, and may also contain sillimanite/kyanite, staurolite, monazite and garnet. In the vast majority of heavy mineral sands, ilmenite is the most abundant heavy mineral and the main mineral, followed by rutile, pseudodrutile (weathered ilmenite) and zircon [1].

Zoning patterns reflect both the chemical substitution processes during crystallization of the source rock and to the weathering processes from the source rock to the deposit area. Fe-Ti oxides concentrates produced from heavy mineral sand deposits are widely used for the production of titanium dioxide pigments that are critical components of white paint, plastics and paper.

According to mining industry, the Fe-Ti concentrates mostly consists of three phases: ilmenite, pseudorutile and rutile. However, mineralogical studies have shown that the variety of Fe-Ti oxides found in sand deposits is far more complex, mostly due to alteration processes. During alteration processes, the Ti content increases. Ilmenite $\left(\mathrm{FeTiO}_{3}\right)$ is progressively transformed into pseudorutile $\left(\mathrm{Fe}_{2} \mathrm{Ti}_{3} \mathrm{O}_{9}\right)$ particles which could also be altered and transformed into hydroxylian pseudorutile $\left[\mathrm{FeTi}_{6} \mathrm{O}_{12}(\mathrm{OH})_{3} \cdot 3 \mathrm{H}_{2} \mathrm{O}\right]$ or complex blends of anatase microcrystals $\left(\mathrm{TiO}_{2}\right)$ [11] [14] [15]. X-ray spectra of pseudorutile and rutile particles show concentrations of Niobium (Figure 10(a) \& Figure 10(b)).

These chemical variations of the titanium oxides have a high impact on the operation with a difficulty of reaching the chemical specificities for each concentrate, the need to vary the parameters of the machines continuously, and finally the difficulty of making good previsions of exploitation with loss of yields.

Zircon develops exclusively through early magmatic crystallization in albite-bearing acidic rocks, i.e. granites, diorites, syenites and their pegmatites. As zircon is ultra-stable in chemical and physical terms, all other reserves, such as 
Table 3. Common heavy mineral in heavy minerals deposits [12].

\begin{tabular}{|c|c|c|c|c|c|c|}
\hline $\begin{array}{l}\text { Heavy } \\
\text { Minerals }\end{array}$ & $\begin{array}{c}\text { Ideal } \\
\text { Composition }\end{array}$ & $\begin{array}{l}\text { Specific } \\
\text { Gravity }\end{array}$ & Hardness & Colour & $\begin{array}{l}\text { Stability in } \\
\text { weathering }\end{array}$ & Provenance \\
\hline Magnetite & $\mathrm{Fe}_{3} \mathrm{O}_{4}$ & 5.2 & $5.5-6.5$ & $\begin{array}{c}\text { black, } \\
\text { dark grey }\end{array}$ & moderate & $\begin{array}{c}\text { igneous \& } \\
\text { metamorphic rocks, } \\
\text { hydrothermal veins }\end{array}$ \\
\hline Monazite & $(\mathrm{Ce}, \mathrm{La}, \mathrm{Y}, \mathrm{Th}) \mathrm{PO}_{4}$ & $4.9-5.5$ & $5-5.5$ & $\begin{array}{l}\text { brownish } \\
\text { red }\end{array}$ & high & $\begin{array}{c}\text { igneous \& } \\
\text { metamorphic rocks }\end{array}$ \\
\hline Iimenite & $\mathrm{FeTiO}_{3}$ & $4.5-5$ & $5-6$ & black & moderate-high & $\begin{array}{c}\text { igneous \& } \\
\text { metamorphic rocks }\end{array}$ \\
\hline Zircon & $(\mathrm{Zr}, \mathrm{Hf}, \mathrm{U}) \mathrm{SiO}_{4}$ & $4.2-4.9$ & $7.5-8$ & many & high & $\begin{array}{c}\text { igneous \& } \\
\text { metamorphic rocks }\end{array}$ \\
\hline Xenotime & $\mathrm{YPO}_{4}$ & $4.4-5.1$ & $4-5$ & $\begin{array}{l}\text { brown, } \\
\text { yellow }\end{array}$ & high & $\begin{array}{c}\text { igneous \& } \\
\text { metamorphic rocks }\end{array}$ \\
\hline Rutile & $\mathrm{TiO}_{2}$ & $4.2-4.3$ & $6-6.5$ & $\begin{array}{l}\text { brownish } \\
\text { red }\end{array}$ & high & $\begin{array}{c}\text { igneous \& } \\
\text { metamorphic rocks }\end{array}$ \\
\hline Corundum & $\mathrm{Al}_{2} \mathrm{O}_{3}$ & 4 & 9 & $\begin{array}{l}\text { colourless, } \\
\text { blue, red }\end{array}$ & low-moderate & $\begin{array}{c}\text { igneous \& } \\
\text { metamorphic rocks }\end{array}$ \\
\hline Leucoxene & $\mathrm{FeTiO}_{3}$ to mostly $\mathrm{TiO}_{2}$ & $3.5-4.5$ & $4-4.5$ & $\begin{array}{l}\text { white to } \\
\text { yellow brown }\end{array}$ & high & $\begin{array}{c}\text { igneous \& } \\
\text { metamorphic rocks }\end{array}$ \\
\hline Staurolite & $\mathrm{Fe}_{2} \mathrm{Al}_{9} \mathrm{O}_{6}\left(\mathrm{SiO}_{4}\right)_{4}(\mathrm{O}, \mathrm{OH})_{2}$ & $3.7-3.8$ & $7-7.5$ & brown & high & metamorphic rocks \\
\hline Garnet & $(\mathrm{Mg}, \mathrm{Fe}, \mathrm{Mn}, \mathrm{Ca}) \mathrm{Al}_{2} \mathrm{Si}_{3} \mathrm{O}_{12}$ & $3.1-4.3$ & $7-7.5$ & $\begin{array}{l}\text { colorless, } \\
\text { all colors }\end{array}$ & moderate & $\begin{array}{c}\text { mostly } \\
\text { metamorphic but } \\
\text { igneous also. }\end{array}$ \\
\hline Kyanite & $\mathrm{Al}_{2} \mathrm{SiO}_{5}$ & $3.5-3.7$ & $4-8$ & $\begin{array}{l}\text { blue, white, } \\
\text { grey, } \\
\text { green, black }\end{array}$ & high & $\begin{array}{l}\text { metamorphic } \\
\text { rocks, rarely in } \\
\text { igneous rocks }\end{array}$ \\
\hline Sillimanite & $\mathrm{Al}_{2} \mathrm{SiO}_{5}$ & 3.2 & $6.5-7.5$ & $\begin{array}{l}\text { colorless, } \\
\text { various } \\
\text { colored }\end{array}$ & high & $\begin{array}{l}\text { metamorphic rocks, } \\
\text { sometimes granite. }\end{array}$ \\
\hline Tourmaline & $(\mathrm{Na}, \mathrm{Ca})(\mathrm{Li}, \mathrm{Mg}, \mathrm{Al})(\mathrm{Al}, \mathrm{Fe}, \mathrm{Mn})_{6}\left(\mathrm{BO}_{3}\right)_{3}\left(\mathrm{Si}_{6} \mathrm{O}_{18}\right)(\mathrm{OH})_{4}$ & $3.0-3.3$ & 7 & $\begin{array}{l}\text { black, } \\
\text { various } \\
\text { colored }\end{array}$ & high & $\begin{array}{l}\text { Granitic pegmatites, } \\
\text { some } \\
\text { metamorphic rocks }\end{array}$ \\
\hline
\end{tabular}

in metamorphites, sediments and also volcanites, can be traced back to zircons initially crystallized in plutonites and later processed/transported [16]. Zircon is a typical placer mineral since it accumulates due to its weathering resistance and high apparent density. This does not apply to metamictic zircons that are unstable because of their physically disrupted crystal lattices. Therefore, these are rarely found in placers and are as a consequence also rare in commercial zircon concentrates. During their transport from the source rock, some zircon particles are coated with iron oxides due to weathering. During the magnetic separation process, these zircon particles coated with iron oxides are thus separated from the purer zircons allowing the production of these two zircon concentrates.

Monazite is present in the MGS. Further studies will make it possible to consider their recovery as a by-product. In some heavy mineral deposits, monazite 
can also be recovered as a by-product for its rare earth element and thorium content. In addition, monazite grains texture and chemical variations marked by large simple to complex zonation can give indications on the nature of the original source rock (magmatic or metamorphic) [17]. Recently monazite has been recovered from beaches and alluvium in India, Malaysia, Sri Lanka, Thailand and Brazil. Placers from Indian beaches are the current main source of monazite production [1]. The mineral associations shown in Figure 7 are confirmed with the BSE images which show many mineral inclusions. Very often, zircon contains inclusions of liquids and/or other minerals (rutile, spinel, feldspar, mica, silica, xenotime, monazite, Al silicates, cassiterite, magnetite and especially apatite). Microcrystalline cracks are a result of metamictization (from the inside) or impacts from the outside [16].

\section{Conclusion}

The mineralogical study of the heavy mineral sands from the Senegalese great coast by Qemscan made allow the quick determination of a large variety of minerals. This rapid analysis methodology nevertheless requires acquiring a solid database for a good interpretation of the results. The minerals identified are all derived from igneous and metamorphic rocks which are most of the source rocks of heavy mineral sand deposits in the world. Observations in scanning electron microscopy show the very wide variety of texture of the titanium oxides and zircon minerals which very often result from the original crystallization conditions of these minerals but also from the alterations they are undergone during their transport from the source rock. Mineralogical examination also indicates the presence of rare earth phosphates such as monazite which are found to be concentrated in quality medium zircon product. further analysis of these monazite particles is necessary to consider their recovery as a by-product at the GCO exploitation.

\section{Acknowledgements}

We graciously thank the Institute for Research and Development (IRD) for funding a large part of the work, as well as the French Embassy, which funded stays in France through a grant. We appreciate the strong participation of the company Grande côte Opérations (GCO) who accepted this study and provided the necessary information and equipment. We would like to thank the Petro-structural laboratory of the Dakar Institute of Earth Sciences and Thin section lab for making and preparing the samples. Finally, we would like to thank the GET laboratory (Geores source environment Toulouse) and Eramet Ideas for carrying out all of the analyzes and their expertise in this study.

\section{Conflicts of Interest}

The authors declare no conflicts of interest regarding the publication of this paper. 


\section{References}

[1] Van Gosen, B.S., Fey, D.L., Salah, A.K., Verplank, P.L. and Hoefen, T.M. (2014) Deposit Model for Heavy-Mineral Sands in Coastal Environments. Scientific Investigations Report 2010-5070-L, United States Geological Survey, Virginia, 51 p. https://doi.org/10.3133/sir20105070L

[2] Roger, J., Noël, B., Barusseau, J., Serrano, O., Nehlig, P. and Duvail, C. (2009) Notice explicative de la carte géologique du Sénégal à 1/500 000, feuilles nord-ouest, nord-est, et sud-ouest. Ministère des Mines, de l'Industrie et des PME, direction des Mines et de la Géologie, Dakar, 61 p.

[3] Fall, M. (1986) Environnements sédimentaires et actuels des tourbières du Sénégal. Thèse de Doctorat de 3éme Cycle, Université Cheikh Anta Diop, Dakar, 136 p.

[4] Sall, M. (1982) Dynamique et morphogénèse actuelles au Sénégal occidental. Thèse Lettres, U.L.P., Strasbourg.

[5] Allouc, J., Sama, J. and Fauvel, P. (1999) Les minbaux ferrotitamk du littoral s6n6galais: Caractérisation et recherche de leur origine. Journal of African Earth Sciences, 28, 553-580. https://doi.org/10.1016/S0899-5362(99)00032-9

[6] Smyte, D., Lombard, A. and Coetzee, L. (2013) Rare Earth Element Deportment Studies Utilising QEMSCAN Technology. Minerals Engineering, 52, 52-61. https://doi.org/10.1016/j.mineng.2013.03.010

[7] Guanira, K., Valente, T., Rios, C., Castellanos, O., Salazar, L., Lattanzi, D. and Jaime, P. (2020) Methodological Approach for Mineralogical Characterization of Tailings from a $\mathrm{Cu}(\mathrm{Au}, \mathrm{Ag})$ Skarn Type Deposit Using QEMSCAN (Quantitative Evaluation of Minerals by Scanning Electron Microscopy). Journal of Geochemical Exploration, 209, Article ID: 106439. https://doi.org/10.1016/j.gexplo.2019.106439

[8] Edahbi , M., Benzazoua, M., Plante, M., Doire, S. and Kormos, L. (2018) Mineralogical Characterization Using QEMSCAN ${ }^{\circledR}$ and Leaching Potential Study of REE within Silicate Ores: A Case Study of the Matamec Project, Québec, Canada. Journal of Geochemical Exploration, 185, 64-73. https://doi.org/10.1016/j.gexplo.2017.11.007

[9] Mackay, D., Simandl, G., Ma, W., Redfearn, M. and Gravel, J. (2016) Indicator Mineral-Based Exploration for Carbonatites and Related Specialty Metal Deposits-A QEMSCAN ${ }^{\circledR}$ Orientation Survey, British Columbia, Canada. Journal of Geochemical Exploration, 165, 159-173.

https://doi.org/10.1016/j.gexplo.2016.03.005

[10] Bernstein, S., Dirk, F., McLimans, R., Knudesn, C. and Vasudev, V. (2008) Application of CCSEM to Heavy Mineral Deposits: Source of High-Ti Ilmenite Sand Deposits of South Kerala Beaches, SW India. Journal of Geochemical Exploration, 96, 25-42. https://doi.org/10.1016/j.gexplo.2007.06.002

[11] Delaporte, A., Blancher, S., Perroton, A. and Wallmach, T. (2019) Detailed Mineralogical Characterization of Leucoxene : A Base for Physical Beneficiation to Improve Rutile Recovery. Heavy Minerals Conference, Cape Town, 5-7 August 2019, 83-95.

[12] Hou, B., Keelin, J. and Van Gosen, B.S. (2017) Geological and Exploration Models of Beach Placer Deposits, Integrated. Ore Geology Reviews, 80, 437-459. https://doi.org/10.1016/j.oregeorev.2016.07.016

[13] Gonçalves, C. and Braga, P. (2019) Heavy Mineral Sands in Brazil: Deposits, Characteristics, and Extraction Potential of Selected Areas. Minerals, 9, 176. https://doi.org/10.3390/min9030176

[14] Delaporte, A., Blancher, S., Goncalves, P. and Wallmach, T. (2018) Physical Property Changes of Fe-Ti Oxides along Their Alteration: A Geometallurgical Study to 
Improve the Yield of a Mineralurgical Plant. IMPC conference, Moscow, 17-21 September 2018, 1-22.

[15] Force, P.S. (1991) Geology of Titanium Mineral Deposits. Geological Society of America Special Paper, 259, 112. https://doi.org/10.1130/SPE259-p1

[16] Elsner, H. (2010) Heavy Minerals of Economic Importance. Assessment Manual Bundesanstalt für Geowissenschaften und Rohstoffe (BGR) (Federal Institute for Geosciences and Natural Resources), 218 p.

[17] Zhu, X. and O’Nions, R.K. (1999) Zonation of Monazite in Metamorphic Rocks and Its Implications for High Temperature Thermochronology: A Case Study from the Lewisian Terrain. Earth and Planetary Science Letters, 171, 209-220.

https://doi.org/10.1016/S0012-821X(99)00146-6 